Sustinere

Journal of Environment and Sustainability

Volume 3 Issue 1 (2019) 24-38

Print ISSN: 2549-1245 Online ISSN: 2549-1253

Website: https://sustinerejes.comE-mail: sustinere.jes@iain-surakarta.ac.id

\title{
RESEARCH PAPER \\ The determinant of sustainable consumption behaviour of Moslem woman in Sukoharjo
}

\author{
Septi Kurnia Prastiwi*,Rabia \\ Department of Sharia Business Management, Faculty of Islamic Business and Economic, IAIN Surakarta, \\ Indonesia \\ Article history: \\ Received 3 February 2019 | Accepted 11 April 2019| Available online 30 April 2019
}

\begin{abstract}
As the increasing of the public consumption pattern, it is followed by environmental pollution offset, which is increasingly alarming. This study aims to analyze how sustainable consumption behavior of Muslim women mediates the intention to behave. Two variables that are thought to influence the sustainable consumption behavior are environmental value and environmental sensitivity by mediating behavioral intention. This study uses a survey method with a population of Muslim mothers in the Sukoharjo area, a sample of 100 respondents, with sampling using a purposive technique, namely judgment sampling, and questionnaires with 12 indicator indicators. The results of the validity, reliability, and classical assumption tests support the continuing research. Results from the path analysis show that the variable 'environmental sensitivity' has a significant effect on behavioral intention and sustainable consumption behavior. Hypothesis test results show that environmental values have a positive and significant effect on behavioral intention and sustainable consumption behavior. The results of the sobel test show that behavioral intention can mediate the relationship between environmental values and the sustainable consumption behavior.
\end{abstract}

Keywords: Sustainable consumption behavior, behavioral intention, environmental value, environmental sensitivity

\section{Introduction}

Environmental pollution in the world, especially in Indonesia is quite alarming as the population in the world increases. The consumption pattern is increasing, accompanied by the development of the industrial world to meet human needs (Ministry of Environment of the Republic of Indonesia, 2013). Food products, daily necessities products such as soap, shampoo, laundry soap, household appliances, electronics, etc. also increasingly vary in type. Almost all products use packaging, whether it's plastic, cans, paper or cardboard. Even now according to Nasution (2015) plastic has dominated the food industry in Indonesia and as a flexible packaging occupies a portion of $80 \%$. Waste in the form of plastic bags can reach 400 tons per 
day, in Jakarta only plastic waste can reach 6000 tons per day (Nasution, 2015). Plastic is a synthetic polymer material that is made through a poly-merization process and is difficult to decompose in nature, to be able to decompose completely takes almost hundreds of years. In fact, data from an estimated 500 million to 1 billion plastic bags are used by the world's population within a period of 1 year (Meirsaguna, 2016).

One step to reduce consumption of products with waste, such as plastic that can pollute the environment is with sustainable consumption behavior in the community. Sustainable consumption behavior is a form of prioritizing shared interests to maintain environmental sustainability. The United Nation Environmental Program in 2013 campaigned "Think Eat Save", as one of the actions to realize sustainable consumption, and aimed at reducing the amount of food waste thrown into the environment (Ministry of Environment of the Republic of Indonesia, 2013). According to the results of a study from Rex and Bauman (2007), individual emotions that are shown to protect the environment and increase individual responsibility will trigger green purchasing decisions. The tendency of consumers to fulfill the desire to seek knowledge about product attributes and product novelty has a beneficial impact on consumer behavior towards purchasing green products (Tanner \& Kast, 2008). Sustainable consumption behavior is also positively influenced by functional value factors, social values, conditional values, environmental values and knowledge values (Biswas \& Roy, 2014).

Sustainable consumption behavior is influenced by intention to behave (Wang et al., 2014). Then there are several factors that can directly influence sustainable consumption behavior and there are those that influence the behavioral mediation intention, namely variable of environmental responsibility, environmental sensitivity, response efficacy, and perceived behavioral control. While the variable of environmental value and environmental knowledge indirectly affects the sustainable consumption behavior with behavioral Intention mediation.

As for the Muslims, that is what Allah Almighty described to Al 'Araaf: 31 that Imam Bukhari explains, Ibnu Abbas said that the meaning is to eat as much as you want and dress as you please when you avoid two things that are excessive and arrogant. From this verse it is clear that Muslims are taught to consume everything properly and not consume anything excessively. The consumption meant here can cover all things that are used such as clothing and things in the form of property. In daily life consumption is only intended as a matter of food and drink (Oktavianti, 2017). Thus, all goods and services utilized by consumers to meet their needs are called consumption expenditures. In this regard, women are one of the holders of consumption control in households whose priorities are as a mother and wife (Oktavianti, 2017). In this case, the Sukoharjo area is more accessible to researchers, after considering limited research time and costs.

Based on the description above, the authors reported the results of research on sustainable consumption behaviors carried out by Muslim women in the form of the application of common sustainable consumption behaviors to those taught by Islam. This study explores further about which variables can encourage consumption behavior of Muslim women to strengthen previous studies which still found a gap in the results of their research. 


\section{Literature review}

\subsection{Sustainable consumption behavior}

Sustainable consumption considers self-improvement, social appreciation, or other immaterial awards. Sustainable consumption can have a positive impact on consumers in reducing consumption, limiting consumption and at the same time excessive forms of anticonsumption practices (Connolly \& Prothero, 2003). Sustainable consumption can support existing and future capabilities that can meet material needs and various other needs that can avoid the impact of environmental damage and loss of function from natural systems (Dimitrova, 2010). Consumption behavior can improve social and environmental performance as well as what they want (Peattie \& Peattie, 2008).

From the explanation above, it can be concluded that sustainable consumption refers to the pattern of reducing consumption of natural resources, changing lifestyle and consumption of products that are environmentally friendly (Biswas \& Roy, 2014). Sustainable consumption is an umbrella condition that can bring all important issues such as self-need, quality of life, maintaining resource efficiency, increasing the use of renewable energy resources, minimizing waste, perspective on the life cycle, and understanding the dimensions of equity.

\subsection{Environmental value}

Hofstede and Bond (1984) suggest that value is a broad tendency to prefer or choose certain circumstances than others. Value is a deep feeling that is owned by the community which will often determine the behavior or behavior of community members. According to PalmerCooper (1998) environmental values are identified through one's perceptions through questions about environmental problems. The results of research from Gumelar (2016), environmental values have a relationship with the formation of environmentally friendly attitudes towards individuals. Environmental value as forming attitudes in individuals has to do with environmental friendliness (Gumelar, 2016). Based on the results of previous research environmental values directly influence behavioral intention (Wang et al., 2014). In this study the hypothesis is as follows:

$\mathrm{H}_{1}$ : Environmental value has a significant effect on behavioral intention

Research from Wang et al. (2014) found several factors that can influence sustainable consumption behavior, namely the variable of environmental value. Environmental knowledge indirectly influences the sustainable consumption behavior with mediation behavioral intention. Other research revealed that positive and significant sustainable consumption behavior was influenced by functional value, social values, conditional value, environmental value and knowledge value (Biswas \& Roy, 2014). So that in this study the hypothesis was raised:

$\mathrm{H}_{2}$ : Environmental value has a significant effect on the sustainable consumption behavior

\subsection{Environmental sensitivity}

Environmental sensitivity is a tendency to recognize the intrinsic value of nature, foster interest in learning about the environment, feeling cared for it, and liking it on the basis of formative experience. Many qualitative studies have found that the sensitivity environment is an important variable in environmental awareness and in predisposing to taking responsible 
environmental actions, where sensitivity is associated with certain types that are significant with life experiences (Chawla, 2010). Having environmental concerns is considered as the main explanation for why individuals carry out sustainability behavior. Environmental attention is a major factor in predicting consumers' purchase intentions to carbonate using and being responsible for ecology (Dermody et al., 2015). So that in this study the following hypothesis was proposed:

$\mathrm{H}_{3}$ : Environmental sensitivity has a significant effect on behavioral intention

The results of the study found several variables of environmental responsibility, environmental sensitivity, perceived behavioral control and significant efficacy responses explained the variable sustainable consumption behavior, and the four variables also indirectly affected the sustainable consumption behavior with behavioral intention mediation (Wang et al., 2014).

$\mathrm{H}_{4}$ : Environmental sensitivity has a significant effect on the sustainable consumption behavior

\subsection{Behavioral intention}

Behavioral intention can be defined as the subjective possibility of individuals who can be involved with behavior. According to Kotler (2009), through experience and learning, people get beliefs and attitudes. Furthermore, beliefs and attitudes influence buying behavior. Confidence is descriptive thinking that someone holds about something as important as attitudes, namely long-term evaluation of one's likes or dislikes, emotional feelings and tendencies to act on some objects or ideas (Kotler \& Keller, 2009).

Assael in Espejel et al. (2007) suggest that our attitude model can appreciate that the attitude of development as a result of a combination of three main elements. These things are related to beliefs, emotions and predict consumer actions: cognitives, affectives, or behaviourals. In particular, this concept reflects the predictions of consumer behavior to be faster in making future purchasing decisions, for example what products / services or brands will be purchased at the next opportunity, etc. Research from Wang et al. (2014) found several factors that can influence sustainable consumption behavior, one of which is the intention to behave. So the hypothesis is determined as follows:

$\mathrm{H}_{5}$ : Behavioral intention significantly influences the sustainable consumption behavior

There are several factors that can directly influence the sustainable consumption behavior and there are those that influence the Behavioral Intention mediation, namely the variable of environmental responsibility, environmental values, environmental sensitivity, response efficacy, and perceived behavioral control (Wang et al., 2014). From this explanation, the hypothesis is as follows:

$\mathrm{H}_{6}$ : Behavioral intention significantly mediates the influence of environmental sensitivity and environmental value on the sustainable consumption behavior.

\subsection{Research Model}

Based on the review results of the literature above, the model taken in this study is shown in Figure 1. The form of the hypothesis is based on data and previous researches that support 
this research, with the research hypothesis as follows. Environmental value has a significant effect on behavioral intention $\left(\mathrm{H}_{1}\right)$. Environmental value has a significant effect on sustainable consumption behavior $\left(\mathrm{H}_{2}\right)$. Environmental sensivity has a significant effect on behavioral intention $\left(\mathrm{H}_{3}\right)$. Environmental sensitivity significantly influences the sustainable consumption behavior $\left(\mathrm{H}_{4}\right)$. Behavioral intention has a significant effect on sustainable consumption behavior $\left(\mathrm{H}_{5}\right)$. The significant behavioral intention mediates the influence of environmental sensitivity and environmental value on the sustainable consumption behavior $\left(\mathrm{H}_{6}\right)$.

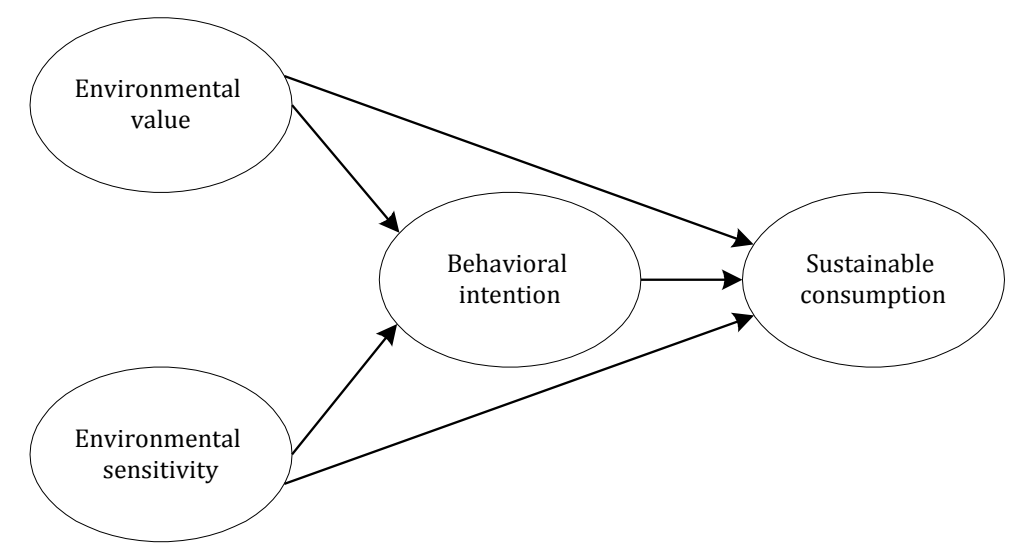

Figure 1. Research framework

\section{Methodology}

This study used a quantitative approach with the ex post facto method, namely the method used to examine events that have occurred and then went backward in succession to find out the causal factors. The design of this study uses descriptive design and regression with mediator variables namely path analysis. In this study, the analyzing data used the SPSS program.

\subsection{Population and Samples}

The population is mothers in Sukoharjo area. The sample in this study was taken as many as 150 respondents. Determination of the number of samples from the population using the Slovin formula (Sugiono, 2011)

\subsection{Techniques of Collecting Data}

Data sources used are from primary data. The criteria that can be achieved in research are Muslim mothers in the Sukoharjo region. The scale used in this study is the interval scales with range of 1 to 10 ranging from strongly disagree to strongly agree.

\subsection{Variable Penelitian}

In this study, there are three types of variables, namely the dependent variable, the independent variable, and the mediating variable. Environmental value is an independent variable which is a special cultural value possessed by each individual (Gumelar, 2016). Environmental sensitivity is an important variable in environmental awareness and in predisposing to taking environmentally responsible actions, where sensitivity is associated with certain types that are significant with life experiences (Chawla, 2010). 
The dependent variable in this study is sustainable consumption behavior which refers to the pattern of reducing consumption of natural resources, changing lifestyles and consumption of environmentally friendly products (Biswas \& Roy, 2014). While the mediator variable, namely behavioral intention, is an individual's motivation for a plan or decision that encourages more specific behavioral performance. Human behavior is generally predictable based on intention, because behavior is controlled by intention, according to Han et al. (2010).

\subsection{Techniques of Analyzing Data}

Before the research was conducted, it was necessary to test the validity and reliability of the list of research questions used. Instrument questionnaires were declared valid if $r>r_{\text {table. }}$. But on the contrary, if $r<r_{\text {table }}$ then the item statement is declared invalid. Meanwhile, the technique used to test reliability is the Cronbach's Alpha technique. In this case, the value of Cronbach's Alpha is said to be reliable if it is in the value range of $0.41-0.60$, quite reliable if the value is between $0.61-0.80$, and if the value of Cronbach's Alpha is between $0.81-100$, it is said to be very reliable (Ghozali, 2016).

Then a regression analysis is performed. Multiple regression is an extension of the regression technique when there are more than one independent variable to make predictions on the dependent variable (Arikunto, 2013). In this study the similarities are as follows:

$$
\begin{aligned}
& z=\alpha+\beta_{1} x_{1}+\beta_{2} x_{2}+\varepsilon \\
& y=\alpha+\beta_{1} x_{1}+\beta_{2} x_{2}+\beta_{3} z+\varepsilon
\end{aligned}
$$

After the model was made, the classic assumption test and the accuracy of the model from the regression analysis results were carried out. In this study, the classic assumption test used was the normality test, multicollinearity test, and heteroskesdatisitas test. Multicollinearity test aimed to test whether the regression model was found to have a correlation between independent variables. Heterokesdasticity test aimed to examine whether in the regression model variance inequality occurs from one residual to another observation.

Next, the model accuracy test was carried out. The test applied in this study was the test of the coefficient of determination $\left(R^{2}\right)$ to see the strength of the relationship between the dependent and independent variables, the $F$ test to see whether the independent variable in unity has met the requirements to be modeled, and the $t$ test to see whether a variable has a significant effect in the model.

In testing the mediating variable, the sobel test was applied to the model. Sobel test used to test whether the influence of variable intervening produced in the path analysis was significant or not. Sobel test requires the assumption of a large number of samples and the mediation coefficient value is normally distributed (Ghozali, 2016). This sobel test was done by testing the strength of the indirect effect of the dependent variable $(x)$ on the independent variable $(y)$ through the intervening variable $(z)$.

The indirect effect of the dependent variable on the independent variable through invening variables calculated by multiplying the path $x \rightarrow y(a)$ with path $z \rightarrow y(b)$ or $a b$. So the coefficient $a b=\left(c-c^{\prime}\right)$, where $c$ is the effect of $x$ on $y$ without controlling $z$, whereas $c^{\prime}$ is the coefficient of 
influence of $x$ on $y$ after controlling $z$. The coefficient errors $a$ and $b$ are written with $s_{a}$ and $s_{b}$, the standard indirect error (indirect effect) $s_{a b}$ is calculated by the following formula:

$$
s_{a b}=\sqrt{b^{2} s_{a}^{2}+a^{2} s_{b}^{2}+s_{a}^{2} s_{b}^{2}}
$$

To test the significance of indirect effects, it is necessary to calculate the value of $t$ from the coefficient ab with the following formula:

$$
t=\frac{a b}{s_{a b}}
$$

This $t_{\text {value }}$ compared with $t_{\text {table }}$ and if $t$ is bigger than $t_{\text {table }}$, so it can be concluded that there is a mediating effect.

\section{Results}

\subsection{Descriptive analysis}

Respondents in this study were mothers in the Sukoharjo area. During the study, 150 respondents were obtained. Summary of descriptive data is shown in Table 1. Based on the table, it can be seen that the majority of respondents studied were 23 year old mothers with an average age of around 37.65 years. Some of them are married with a number of children around 2 people, with the most monthly income between 1 and 2 million per month. The work of respondents is dominated by housewives with the majority education are high school.

Table 1. Analysis of descriptive

\begin{tabular}{lccccc}
\hline & $\begin{array}{c}\text { Amount of } \\
\text { data }(n)\end{array}$ & $\begin{array}{c}\text { Mean } \\
(\mu)\end{array}$ & Median & Mode & $\begin{array}{c}\text { Std Dev } \\
(\sigma)\end{array}$ \\
\hline Age & 150 & 37.65 & 37.00 & 23 & 11.662 \\
Number of children & 150 & 2.0315 & 2.00 & 2 & 1.570 \\
Monthly household income & 150 & 2.03 & 2.00 & 2 & 0.850 \\
Job & 150 & 2.03 & 1.00 & 1 & 1.312 \\
Education & 150 & 2.11 & 2.00 & 2 & 0.775 \\
\hline
\end{tabular}

Remarks: jobs with code 1 are housewives and code 2 is self-employed, Education of respondents with code 2 is high school

\subsection{Validity and reliability data analysis}

As mentioned in the data processing technique that is reliable if the value is between 0.61 0.80 , and if the Cronbach's Alpha value is between $0.81-1.00$ then it is said to be very reliable (Ghozali, 2016). According to Nunnally in Ghozali (2016) a construct or variable is said to be reliable if it gives the value of Cronbach Alpha $>0.70$. After all indicators are tested, it is known that all indicators have a Cronbach Alpha value $>0.70$, so it can be concluded that all question indicators are reliable (Tabel 2).

The results of factor rotation as shown in Table 3 with the varimax method show that the indicators of environmental sensitivity, environmental values, behavioral intention, and the injectable consumption behavior all have a loading factor above 0.5 and group together into their respective factors. Thus, it can be concluded that the construct of environmental sensitivity has unidimensionality as well as the construct of environmental value, behavioral intention and injectable consumption behavior or in other words all indicators are valid. 
Table 2. Test of data reliability

\begin{tabular}{lcc}
\hline \multicolumn{1}{c}{ Variabel } & Cronbach Alpha & Decision \\
\hline Environmental sensitifity & 0.713 & Quite reliable \\
Environmental value & 0.924 & Very reliable \\
Behaviour intention & 0,752 & Quite reliable \\
Sustainable consumption Behaviour & 0.760 & Quite reliable \\
\hline
\end{tabular}

Tabel 3. Test of data validity

\begin{tabular}{lccc}
\hline \multicolumn{1}{c}{ Variabel } & Indicators & Loading factor & Decision \\
\hline Environmental sensitifity & Es1 & 0.508 & Quite reliable \\
& Es2 & 0.602 & Quite reliable \\
Environmental Value & Ev1 & 0.889 & Very reliable \\
& Ev2 & 0.897 & Very reliable \\
& Ev3 & 0.804 & Very reliable \\
Behavioral Intention & Bi1 & 0.732 & Very reliable \\
& Bi2 & 0.633 & Quite reliable \\
Sustainable Consumption & Bi3 & 0.670 & Quite reliable \\
Behavior & Scb1 & 0.546 & Quite reliable \\
& Scb2 & 0.685 & Quite reliable \\
& Scb3 & 0.816 & Very reliable \\
& Scb4 & 0.669 & Quite reliable \\
& Scb5 & 0.640 & Quite reliable \\
\hline
\end{tabular}

\subsection{Testing Model}

The tolerance value in Table 4 shows that there is no independent variable that has a tolerance value of less than 0.10 which means there is no correlation between the independent variables. The results of the Variance Inflation Factor (VIF) value of all the independent variables of the VIF value are not more than 10. Thus, there is no multicollinearity between the independent variables in the regression model. Heterokesdasticity test aims to test whether in the regression model there is a variance of residual inequality, one observation to another observation (Ghozali, 2016). The results of heteroscedasticity test are shown in Table 5. Heteroscedasticity test with glacier test, if the statistically significant independent variables affect the dependent variable, then there is an indication of heteroscedasticity. The results of the SPSS output display clearly indicate that the independent variable is the sig value. All above 0.05 so that nothing significantly affects the dependent variable. So, it can be concluded that the regression model does not contain any heteroscedasticity.

Table 4. Multicolinierity test

\begin{tabular}{lll}
\hline \multicolumn{1}{c}{ Variabel } & Tolerance & VIF \\
\hline Model 1 & 0.751 & 1.322 \\
$\quad$ Environmental sensitivity $\left(x_{1}\right)$ & 0.751 & 1.322 \\
$\quad$ Environmental value $\left(x_{2}\right)$ & & \\
Model 2 & 0.713 & 1.403 \\
$\quad$ Environmental sensitivity $\left(x_{1}\right)$ & 0.640 & 1.563 \\
$\quad$ Environmental value $\left(x_{2}\right)$ & 0.699 & 1.430 \\
Behaviour intention $(z)$ & & \\
\hline
\end{tabular}


Table 5. Heteroscedastisity test

\begin{tabular}{lcc}
\hline \multicolumn{1}{c}{ Variabel } & Sig. & Decision \\
\hline Model 1 & & \\
$\quad$ Environmental sensitivity $\left(x_{1}\right)$ & 0.729 & Homoscedasticity \\
$\quad$ Environmental value $\left(x_{2}\right)$ & 0.071 & Homoscedasticity \\
Model 2 & & \\
$\quad$ Environmental sensitivity $\left(x_{1}\right)$ & 0.864 & Homoscedasticity \\
$\quad$ Environmental value $\left(x_{2}\right)$ & 0.166 & Homoscedasticity \\
$\quad$ Behaviour intention $(z)$ & 0.462 & Homoscedasticity \\
\hline
\end{tabular}

The Kolmogorov Smirnov statistic test value (see Table 6) is 1.323 and significant at 0.061 above $\alpha=0.05$. This means that $\mathrm{H}_{0}$ is fail to be rejected, so the residual data is normally distributed. Model 2 is a significant value above 0.05 so that the residual data is normally distributed. Then the model accuracy test is done by looking at the coefficient of determination $\left(R^{2}\right)$. In determination coefficient is measuring how far the ability of the model in explaining the variation of the dependent variable (Ghozali, 2016). The results of the accuracy tests of Model 1 and Model 2 are shown in Table 7.

Table 6. Kolomogorov test for normality testing

\begin{tabular}{cccc}
\hline Remark & $\mathrm{N}$ & $\begin{array}{c}\text { Kolmogorov } \\
\text { Smirnov }\end{array}$ & $\begin{array}{c}\text { Asymp.Sig. } \\
\text { (2-tailed) }\end{array}$ \\
\hline Model 1 & 150 & 0.76 & 0.053 \\
Model 2 & 150 & 1.323 & 0.061 \\
\hline
\end{tabular}

Table 7. Kolomogorov test for normality testing

\begin{tabular}{ccccc}
\hline Model & $R$ & $R^{2}$ & Adjusted $R^{2}$ & $\begin{array}{c}\text { Std. Error of the } \\
\text { Estimate }\end{array}$ \\
\hline Model 1 & $.548^{\mathrm{a}}$ & .301 & .291 & 3.997 \\
Model 2 & $.660^{\mathrm{a}}$ & .435 & .424 & 6.404 \\
\hline
\end{tabular}

In Table 8, it can be seen that Model $1, R^{2}$ is 0.30 . This means that $30 \%$ of the variables of environmental sensitivity and environmental value influence behavioral intention and $70 \%$ are influenced by other variables outside of this research model. While the value of $R^{2}$ for Model 2 is 0.43 , which means that $43 \%$ of the variables of behavioral intention, environmental value and environmental sensitivity affect the sustainable consumption behavior. The rest, $57 \%$ is influenced by other variables outside of this research model. 
Table 8. $F$ test for Model 1 and Model 2

\begin{tabular}{llccccc}
\hline \multirow{2}{*}{ Model } & Sum of Squares & Df & Mean Square & F & Sig. \\
\hline \multirow{2}{*}{ Model 1 } & Regression & 1010.102 & 2 & 505.051 & 31.617 & $.000^{\mathrm{a}}$ \\
& Residual & 2348.192 & 147 & 15.974 & & \\
& Total & 3358.293 & 149 & & & \\
\hline \multirow{3}{*}{ Model 2 } & Regression & 4614.431 & 3 & 1538.144 & 37.500 & $.000 \mathrm{a}$ \\
& Residual & 5988.562 & 146 & 41.018 & & \\
& Total & 10602.993 & 149 & & & \\
\hline
\end{tabular}

The ANOVA test results of Models 1 and 2 are shown in Table 8. From these results, Model 1 and Model 2 have $F$ counts of 31.617 and 37.5 with the probability of each being 0.000 . Because the probability on both models is much smaller than 0.05, then Model 1 can be used to predict behavioral intention and Model 2 can be used to predict sustainable consumption behavior.

Next to test the model parameters, the results are shown in Table 9. Based on the table, in Model 1 the $t$ calculates the variable of environmental value of 5.051 and the value of $t_{\text {table }}$ for $N=$ 150 with an error rate of $5 \%$ is 1.98 . This number shows $t>t_{\text {table }}$ and the significant value is 0.000 which is smaller than $0.05 . \mathrm{H}_{0}$ was rejected at a confidence level of $95 \%$, meaning that there is a significant influence between the environmental value on the behavioral intention. The results of this study are in line with the results of research from Wang et al. (2014) that environmental values directly influence behavioral intention. Based on the table, in Model 1, the $t$ calculates the variable of environmental sensitivity of 2.802 and the value of $t$ for $N=150$ with an error rate of $5 \%$ is 1.98 . This number shows $t>t_{\text {table }}$ and Significant value (0.006) is smaller than $0.05 . \mathrm{H}_{0}$ was rejected at a confidence level of $95 \%$, meaning that there was a significant influence between the environmental sensitivity to behavioral intention. The results of this study support the results of research by Wang et al. (2014) that environmental sensitivity directly affects behavioral intention.

Table 9. Results of Multiple linear regression test

\begin{tabular}{|c|c|c|c|c|c|c|}
\hline & \multirow[t]{2}{*}{ Model } & \multicolumn{2}{|c|}{$\begin{array}{l}\text { Unstandardized } \\
\text { Coefficients }\end{array}$} & \multirow{2}{*}{$\frac{\begin{array}{c}\text { Standardized } \\
\text { Coefficients }\end{array}}{\text { Beta }}$} & \multirow[t]{2}{*}{$t$} & \multirow[t]{2}{*}{ Sig. } \\
\hline & & $B$ & Std. error & & & \\
\hline \multirow{3}{*}{ Model 1} & Constant & 8.460 & 2.081 & & 4.066 & .000 \\
\hline & Environmental sensitivity $\left(x_{1}\right)$ & .385 & .137 & .223 & 2.802 & .006 \\
\hline & Environmental value $\left(x_{2}\right)$ & .350 & .069 & .402 & 5.051 & .000 \\
\hline \multirow{4}{*}{ Model 2} & Constant & 1.693 & 3.517 & & .481 & 631 \\
\hline & Environmental sensitivity $\left(x_{1}\right)$ & .780 & .226 & .255 & 3.457 & .001 \\
\hline & Environmental value $\left(x_{2}\right)$ & .390 & .120 & .252 & 3.242 & .001 \\
\hline & Behaviour intention $(z)$ & .550 & .132 & .310 & 4.163 & .000 \\
\hline
\end{tabular}


Based on the results of the hypothesis 1 test, the results of environmental sensitivity have a significant effect on behavioral intention. While the results of hypothesis 2 test show that the environmental value has a significant effect on behavioral intention

Based on Table 9, in Model 2 the $t$ of the variable of environmental sensitivity (es) is 3.457 and the value of $t_{\text {table }}$ for $N=150$ with an error rate of $5 \%$ is 1.98 . This number shows that $t>$ $t_{\text {table }}$ and Significant value of 0.001 is smaller than $0.05 . \mathrm{H}_{0}$ is rejected at a confidence level of $95 \%$, meaning that there is a significant influence between environmental sensitivity to the sustainable consumption behavior. The results of this study support the research results by Wang et al. (2014) that environmental sensitivity has a significant effect on sustainable consumption behavior.

Meanwhile, the $t$ of the environmental value $(\mathrm{ev})$ variable is 3.242 and the $T_{\text {value }}$ for $N$ is equal to 150 with an error rate of $5 \%$ is 1.98 . This number shows $t>t_{\text {table }}$ and the significant value of 0.001 is smaller than 0.05 . $\mathrm{H}_{0}$ was rejected at a confidence level of $95 \%$, meaning that there is a significant influence between the environmental value and the sustainable consumption behavior. The results of this study are in line with the results of research from Wang et al. (2014).

Based on the table above, it can be seen that the $t$ value of the variable of behavioral intention (bi) is 4.663 and the value of $t$ table for $N=150$ with an error rate of $5 \%$ is 1.98 . This number shows $t>t_{\text {table }}$ and the value of significancy is 0.000 which is smaller than $0.05 . \mathrm{H}_{0}$ was rejected at a confidence level of 95\%, meaning that there is a significant influence between the behavioral intention towards the sustainable consumption behavior. The results of this study are in line with the results of research from Wang et al. (2014).

Based on the results of the hypothesis 3 test, the results of environmental sensitivity have a significant effect on the sustainable consumption behavior. While the results of hypothesis 4 test show that the environmental value has a significant effect on the sustainable consumption behavior. The results of the study prove that $\mathrm{H}_{5}$ behavioral intention can significantly influence the sustainable consumption behavior.

From the results of testing the hypothesis above it can be seen that these results strongly support the hypothesis and do not conflict with Islamic teachings that humans are encouraged to have non-excessive consumption behavior, which must think about future life and not damage the environment. This supports verse of $\mathrm{Al}$ 'Araaf: 31 which was explained in the introduction to the study. In this case, Muslim women who play a dominant role in purchasing activities in household consumption have proven that their behavior has led to sustainable consumption behavior.

\section{Sobel Test}

To test the Hypothesis 6, does the significant behavioral intention mediate the relationship between the environmental value and the environmental sensitivity to the sustainable consumption behavior, then it is tested by a single test. Next will be a sobel test between the variables of environmental sensitivity to the sustainable consumption behavior and mediation of behavioral intention. The value of unstandardized beta coefficient 0.550 is the value of path $p_{2}$. Beta unstandardized value of environmental sensitivity variable 0.385 is the value of path $p_{1}$ and 
unstandardized beta value Behavioral intention to sustainable consumption behavior 0.550 is the value of path $p_{3}$.

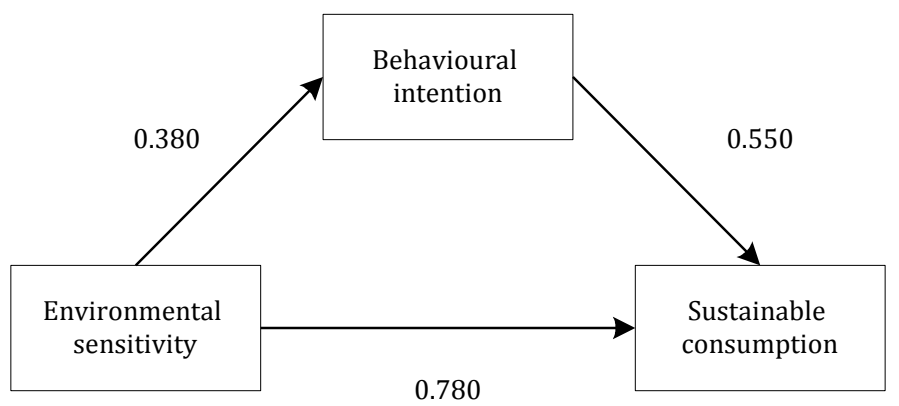

Figure 2. Research results model

The results of path analysis show that environmental sensitivity can directly influence the sustainable consumption behavior of 0.780 , but it can indirectly affect the sustainable consumption behavior, namely by mediating behavioral intention. The magnitude of the indirect effect must be calculated by multiplying the indirect coefficient namely; $0.385 \times 0.550=0.211$. The influence of mediation indicated by the multiplication of the coefficients $p_{2}$ and $p_{3}$ is 0.21 significant or not tested with the sobel test, as follows:

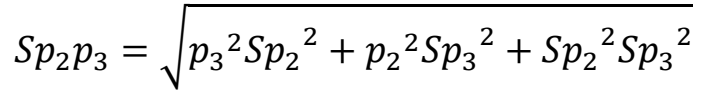

$$
\begin{aligned}
& S p_{2} p_{3}=\sqrt{(0.550)^{2}(0.132)^{2}+(0.385)^{2}(0.137)^{2}+(0.132)^{2}(0.137)^{2}} \\
& t=p_{2} p_{3}=2.32
\end{aligned}
$$

The value of $t=2.32$ is greater than $t_{\text {table }}$ with a significance level of 0.05 that is equal to 1.66 , so it can be concluded that the mediation coefficient of 0.21 is significant, which means that there is the influence of partial mediation. Because of the magnitude of the direct influence is greater between the environmental sensitivity variable on the sustainable consumption behavior than the indirect influence with mediation behavioral intention.

Next, will be a sobel test between the variables of environmental value and the sustainable consumption behavior with mediation behavioral intention. Unstandardized coefficient value of beta 0.390 is $p_{2}$ path value. The unstandardized beta environmental value of 0.350 is the path $p_{1}$ path value and the unstandardized beta value Behavioral intention to sustainable consumption behavior 0.550 is the value of path $p_{3}$. 


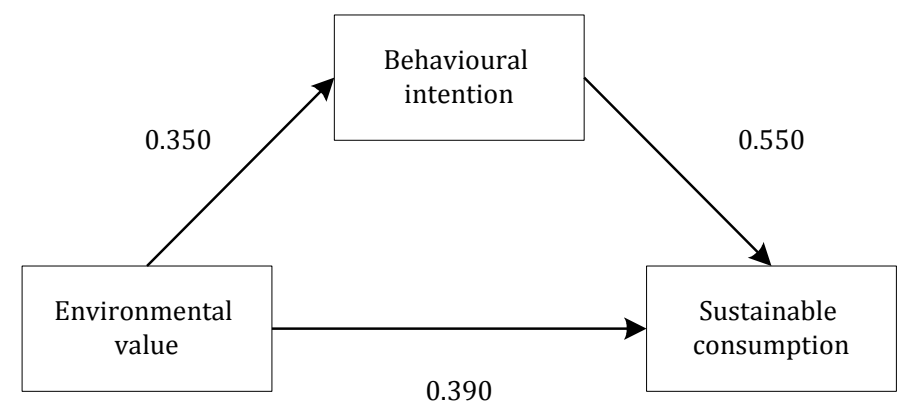

Figure 3. Research Results Model

The results of the path analysis show that environmental values can directly influence the sustainable consumption behavior of 0.390 , but can indirectly affect the sustainable consumption behavior, namely by mediating behavioral intention. The magnitude of the indirect effect must be calculated by multiplying the indirect coefficient namely; $0.350 \times 0.550=0.192$. The influence of mediation shown by the multiplication of $p_{2}$ and $p_{3}$ coefficients is 0.192 significant or not tested with the sobel test, as follows:

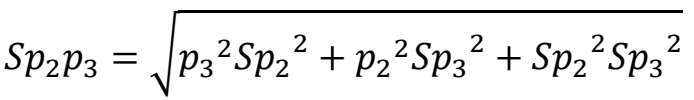

$$
\begin{aligned}
& S p_{2} p_{3}=\sqrt{(0.550)^{2}(0.069)^{2}+(0.350)^{2}(0.132)^{2}+(0.069)^{2}(0.132)^{2}} \\
& t=p_{2} p_{3}=3.29
\end{aligned}
$$

The value of $t=3.29$ is greater than $t$ table with a significance level of 0.05 which is equal to 1.66 , so it can be concluded that the mediation coefficient of 0.192 is significant, which means that there is an influence of partial mediation. Because the magnitude of the direct influence is greater between the variable of environmental value and the sustainable consumption behavior than the indirect influence of mediation behavioral intention.

\section{Conclusions}

The conclusion of this study shows that the variable of environmental sensitivity has a significant effect on behavioral intention and sustainable consumption behavior. Hypothesis test results show that environmental values have a positive and significant effect on behavioral intention and sustainable consumption behavior. The results of the sobel test show that behavioral intention can mediate the relationship between environmental values and the sustainable consumption behavior.

Mothers have an important role in making household consumption decisions. It is expected that mothers can always carry out sustainable consumption behaviors and teach and educate children about sustainable consumption behavior. For the company, the environmental value and environmental sensitivity proved to have a direct and significant effect on the sustainable consumption behavior. In addition, producers can create products that have a positive impact on the environment, value the environment, then marketers can communicate the superiority of products that have more value to the environment to the community, so that they can prefer 
their products that are more environmentally friendly. Making promotional material and product information that can attract empathy, sensitivity and exceptions to the environment.

This study has several limitations, including the number of objects restricted to mothers and in the Sukoharjo region, so that research can be carried out with a wider range of objects and regions. Therefore, more accurate generalizations of research results can be drawn.

\section{Acknowledgement}

This research is sponsored by Biaya Operasional Perguruan Tinggi Negeri (BOPTN) IAIN Surakarta.

\section{References}

Arikunto, S. (2013). Prosedur Penelitian. Jakarta: Rineka Cipta.

Biswas, A., \& Roy, M. (2014). Green Products: An Exploratory Study on the Consumer Behaviour in Emerging Economies of the East. Journal of Cleaner Production. http://doi.org/10.1016/j.jclepro.2014.09.075

Chawla, L. (2010). Significant Life Experiences Revisited: A Review of Research on Sources of Environmental Sensitivity. The Journal of Environmental Education, 29(3), 11-21. http://doi.org/10.1080/00958969809599114

Connolly, J., \& Prothero, A. (2003). Sustainable consumption: consumption, consumers and the commodity discourse. Consumption Markets \& Culture, 6(4), 275-291. http://doi.org/10.1080/1025386032000168311

Dermody, J., Hanmer-Lloyd, S., Koenig-Lewis, N., \& Zhao, A. L. (2015). Advancing sustainable consumption in the UK and China: the mediating effect of pro-environmental self-identity. Journal of Marketing Management, 31(13-14), 1472-1502. http://doi.org/10.1080/0267257X.2015.1061039

Dimitrova, P. S. (2010). Sustainable Consumption. Literature review on sustainable consumption practices and the attitude-behaviour gap. Aarhus School of Business.

Espejel, J., Fandos, C., \& Flavia, C. (2007). The role of intrinsic and extrinsic quality attributes on consumer behaviour for traditional food products. Managing Service Quality, 17(6), 681701. http://doi.org/10.1108/09604520710835000

Ghozali, I. (2016). Aplikasi Analisis Multivariate dengan Program SPSS. Semarang: Badan Penerbit Universitas Diponegoro.

Gumelar, G. (2016). Lingkungan Dan Sikap Ramah Lingkungan Pada Warga Jakarta Di Pemukiman Kumuh. Psikologi, 12.

Han, H., Hsu, L. T. (Jane), \& Sheu, C. (2010). Application of the Theory of Planned Behavior to green hotel choice: Testing the effect of environmental friendly activities. Tourism Management, 31(3), 325-334. http://doi.org/10.1016/j.tourman.2009.03.013

Hofstede, G., \& Bond, M. H. (1984). Hofstede's culture dimensions. An independent validation using Rokeach's Value Survey. Journal of Cross-Cultural Psychology1, 15(4), 417-433.

Kotler, P., \& Keller, K. L. (2009). Manajemen Pemasaran (Edisi 12). Jakarta: PT INDEKS. 
Meirsaguna, D. A. (2016). Fotografi dokumenter program diet kantong plastik sebagai upaya. Universitas Pasundan.

Ministry of Environment The Republic of Indonesia. (2013). State of the Environment Report Indonesia 2012 Pillars of the Environment of Indonesia. Annual Review of Environment and Resources (Vol. 28). http://doi.org/10.1146/annurev.energy.28.050302.105509

Nasution, R. S. (2015). Berbagai cara penanggulangan limbah plastik. Elkawnie: Journal of ISlamic Sciene and Technology, 1(1), 97-104.

Oktavianti, H. (2017). Perilaku Konsumsi Rumah Tangga Dan Pengaruhnya Terhadap Kebijakan Makro Ekonomi Kabupaten Bangkalan. Media Trend, 12(1). http://doi.org/10.21107/mediatrend.v12i1.2728

Palmer-Cooper, J. A. (1998). Spirit of the environment: Religion, value, and environmental concern. Taylor \& Francis.

Peattie, K., \& Peattie, S. (2008). Social marketing: A pathway to consumption reduction ? Journal of Business Research, 62(2), 260-268. http://doi.org/10.1016/j.jbusres.2008.01.033

Rex, E., \& Baumann, H. (2007). Beyond ecolabels: what green marketing can learn from conventional marketing. Journal of Cleaner Production, 15(6), 567-576. http://doi.org/10.1016/j.jclepro.2006.05.013

Sugiono. (2011). Metode Penelitian Kuantitatif,Kualitatif dan R\&D. Bandung: Alfabeta.

Tanner, C., \& Kast, S. W. (2008). Consumption: Determinants of Green Purchases by Swiss. Psychology \& Marketing, 20(10), 883-902. http://doi.org/10.1002/mar.10101

Wang, P., Liu, Q., \& Qi, Y. (2014). Factors influencing sustainable consumption behaviors: a survey of the rural residents in China. Journal of Cleaner Production, 63, 152-165. http://doi.org/10.1016/j.jclepro.2013.05.007 